\title{
The Influence of Intellectual Capital on Firms Performance of Indian Automobile Industry
}

\author{
Thanikachalam Vadivel, Selvam Murugesan, Amrutha Pavithran, Gayathri Jayapal
}

\begin{abstract}
The aim of the paper was to investigate, the effect of intellectual capital on the financial performance of automobile companies in India. The required information was gathered from Indian automobile companies, between 2009 and 2018 and the (MVAIC) was employed for measuring the intellectual capital. Indian automobile firms efficiently utilized their IC. MVAIC created the effect on financial performance of sample firms. The contribution of IC to financial performance has been consistently recorded in the firms' performance of Indian automobile companies. The present research would provide the knowledge on IC to academicians and managers, by highlighting its contributions to value creation of sample firms. The results would help the stakeholders and policymakers, in emerging automobile industry in India, by properly reallocating intellectual resources for effective use.
\end{abstract}

Keywords: Automobile Industry, Modified Value Added Intellectual Coefficient, and Financial Performance.

\section{INTRODUCTION}

In this globalized era, the growth of technologically advanced companies has increased the necessity for the use of intellectual capital. Due to the development of knowledge-driven firms, the determinants of production and value creation have moved from tangible resources (capital, plant and machinery) to knowledge-embedded workers of the firms (Vishnu and Gupta, 2014). It is essential for the firms to be aware of different components of intellectual capital that would provide value creation to firms. It is inevitable fact that traditional financial mechanism did not disclose all the factors for creating new values and report them to the stakeholders of firms. Hence, there is an urgent need for an effective and standard reporting (Jamal A. Nazari and Irene M. Herremans, 2007). Several studies have attempted to find out valid methods, so as to measure the intellectual capital of firms. Failure of traditional performance measures prompted the management to adopt a fresh approach to the contributions of intellectual capital, that directly or indirectly, influenced the financial performance of the firms (Mondal and Ghosh, 2015). Neoclassical economies

Revised Manuscript Received on November 11, 2019.

* Correspondence Author

Thanikachalam Vadivel, Ph. D., Research Scholar in Management, Department of Commerce and Financial Studies, Bharathidasan University, Tamil Nadu, India.

Selvam Murugesan, Dean,Faculty of Management, Professor and Head, Department of Commerce and Financial Studies, Bharathidasan University, Tamil Nadu, India.

Amrutha Pavithran, Ph. D., Research Scholar in Management, Department of Commerce and Financial Studies, Bharathidasan University, Tamil Nadu, India.

Gayathri Jayapal, Assistant Professor of Dept. of Commerce and Financial Studies, BDU,Trichy, Tamil Nadu. emphasized utilization of physical capital (Pek Chen Goh, 2005). At present, the intangible resources have become drivers of successful corporations. Companies, with vision, have already realized the need for measuring and managing these assets as carefully as they treat their tangible assets (Jyotirmayee Choudhury, 2010). There is an urgent need for adoption and execution of suitable manufacturing suggestion along with low cost technologies, resulting in high quality products. Hence, the need for appropriate measurement of intellectual capital is to be developed for its management and preparation of corporate reporting. Academicians and practitioners have already recommended various models, to measure IC and its components (Vishnu and Gupta, 2014). There are different methods, developed by leading researchers, to measure intellectual capital, the most familiar method is the Skandia Navigator method, created by Edvinsson and Malone (1997). Sveiby's (1997) recommended the Intangible Assets Monitor. Kaplan and Norton (1996) preferred the Balanced Scorecard approach. Pulic (2000) designed the Value-Added Intellectual Coefficient (VAIC). Clarke et al. (2011) listed out the difficulties of measuring intellectual capital such as the non-availability of required information. The main trouble with intellectual capital is that it cannot be perfectly converted into financial term (Neha Smriti and Niladri Das, 2018). Against this background, researchers have predominantly employed the VAIC model, to assess the impact of intellectual capital on the financial performance of firms (Ahangar, 2011; Bontis et al., 2000; Chen et al., 2005; Selvam Murugesan et al., 2018; Murugesan Selvam et al., 2019). Automobile industry in India has emerged as one of the rapid growing industries in India and it would become one of the global leaders in the near future. It attracted huge foreign investments in the past few years. It is to be noted that automobile exports grew by 20.78 per cent, during 2018, in India. Automobile industry in India is likely to reach 8-12 per cent hike, in its hiring, during FY19 (India Brand Equity Foundation, 2019). This study aims to examine the financial performance of sample industry, using the widely practised traditional measure of performance. This study has proposed to use four indicators like Return On Assets, Asset Turnover Ratio, Return On Equity and Return On Net Worth. The paper was designed into five sections. Section-2 deals with the literature review in connection with intellectual capital, measurement of firm performance. Section-3 discusses the sample variables and research methodology, adopted in this study. Section-4 and 5 deal with the findings of the empirical analysis and discussion of the results respectively, followed by

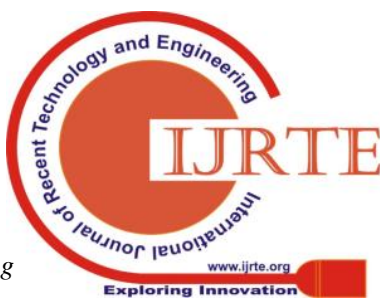


limitations and future implications in the last section.

\section{A. Problem Statement} terms of monetary values, is a tough task. The accounting standards, adhered by corporate firms across the globe, did intellectual capital is in their infancy stage. The quality of personnel resources has been an inevitable and proactive concern in developing countries because a skillful workforce can enhance the sustainable development of firm through its competitiveness. Against this background, this current study investigated the influence of intellectual capital on the financial performance of automobile sector in India, which is an important sector amid most capital and knowledge-required and rapid-growing sectors in India and it contributes a substantial portion of the foreign exchange income to India.

\section{B. Need of the Study}

The present study tries to fill the research gap found in the literature, by exploring the effect of intellectual capital on financial performance of automobile companies in India. The results of this research study would be fruitful for sample companies, seeking to measure the intellectual capital performance and would also offer insights into critical issues faced by sample firms. Besides, the stakeholders of sample firms could obtain valuable insights into the factors leveraging the performance of firms in the future.

\section{Objective of the Study}

The prime motto of this current study was to reveal the efficiency of intellectual capital of automobile industry in India and to test the correlation and regression of the scale in respect of relationship and impact, through an empirical study.

\section{Null-Hypotheses of the Study}

NH-1: No relationship between Modified Value Added Intellectual Coefficient and the financial performance of Automobile Industry in India

NH-2: No impact of Modified Value Added Intellectual Coefficient on the financial performance of Automobile Industry in India

\section{LITERATURE REVIEW}

Definitions and classifications on intellectual capital differ with each researcher. Intellectual capital is an intangible resource, with a capacity to promote values for the firms in particular and the society in general (Mouritsen et al., 2001). According to Roos et al., 1997, VAIC is quantifiable and amenable to quantitative measurements, without being tainted by any subjective assessment. Human capital is the collective value, resulting from experience and training. Structural Capital could be fragmented into two categories. The first category consists of databases, patents, copyrights and trademarks. The next category covers infrastructural resources (Keong Choong, 2008). Effective management on customer relationships of a firm is called as relational capital (Tether and Tajar, 2008). It is found from the annual
The measurement of intellectual capital successfully, in not mandate disclosure practice about intellectual capital. In emerging countries such as India, the disclosure of

reports of the company, listed at Lahore Stock Exchange (Pakistan) that the companies had witnessed the best intellectual capital performance Makki et al. (2009). According to, Clarke et al. (2011), there was a correlation between Value-Added Intellectual Coefficient (VAIC) and firms' performance. Bramhandkar et al. (2007) showed that the firms, with more intangible assets, performed better than those with mere quantity of intellectual capital. There is growing realization of the significance of intangible assets and its role in enhancing market values (Dzenopoljac et al., 2016). Developing countries shape their strategies taking the findings of previous studies on intellectual capital by the previous researchers. The study by Chen and Hwang (2005) examined the effect of intellectual capital on market value, and the financial performances of the sample companies in Taiwan. Morariu (2014) identified that companies in Romania, creating value by their intangible resources, did not perform well in the stock market. It is to be noted that intellectual capital enhances firm performance (Nadeem et al., 2017). Kamath (2008) found that human capital has created a tremendous impact only on ROA in the Indian pharmaceutical sector. Ranjith Appuhami (2007) found that investors' capital gain on shares was positively affected by intellectual capital. Hong Pew Tan et al., (2007) have witnessed a significant association between intellectual capital and financial performance of sample firms through the empirical study.

\section{METHOD}

The investments from India and abroad have been hugely attracted by automobile sector in India. The arrival of FDI was US\$ 19.29 billion, to automobiles sector, from 2000 to 2018. Besides, adoption of innovations are perhaps essential for every firm to intensify among technology and alternative fuels. Thus, automobile industry has been playing an active role in the Indian economy. Against this background, it was decided to select NSE Nifty automobile industry as sample for this study, which has selected top 15 automobile firms. The data was collected from PROWESS. This study covered a span of ten years, from 01-01-2009 to 31-12-2018 since during period the Indian Automobile sector had achieved tremendous growth. For the purpose of analysis, MVAIC was used as follows.

$$
\begin{aligned}
& \text { MVAIC }=\text { HCE }+ \text { SCE }+ \text { CEE }+ \text { RCE } \ldots . . . . .(1) \\
& \text { Value Added = Operating Profit }+ \text { Employee Cost }+ \\
& \text { Depreciation }+ \text { Amortization } \\
& \mathrm{HCE}=(\mathrm{VA} / \mathrm{HC}) \\
& \mathrm{HC}=(\text { salaries employee are considered an investment }) \\
& \mathrm{SCE}=(\mathrm{SC} / \mathrm{VA}) \\
& \mathrm{SC}=(\mathrm{VA}-\mathrm{HC}) \\
& \mathrm{CEE}=(\mathrm{VA} / \mathrm{CE}) \\
& \mathrm{CE}=\text { capital employed in the business } \\
& \mathrm{RCE}=(\mathrm{RC} / \mathrm{VA} \\
& \mathrm{RC}=\text { advertising expenses and marketing expenses }
\end{aligned}
$$

Dependent variables included ATO, ROA, ROE and RONW.

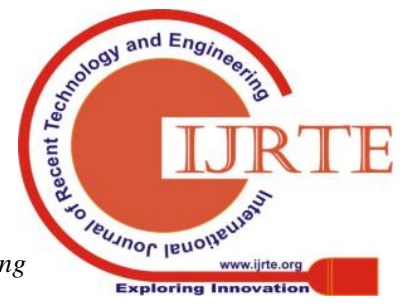


Model 1: $\mathrm{ATO}=\beta 0+\beta 1 \mathrm{HC}+\beta 2 \mathrm{SC}+\beta 3 \mathrm{CE}+$ $\beta 4 \mathrm{RC}+\beta 5 \ln \mathrm{FSize}+\beta 6 \mathrm{Lev}+\varepsilon \ldots \ldots .(2)$ Model $2: \mathrm{ROA}=\beta 0+\beta 1 \mathrm{HC}+\beta 2 \mathrm{SC}+\beta 3 \mathrm{ICE}+$ $\beta 4 \mathrm{RC}+\beta 5 \ln F$ Size $+\beta 6 \mathrm{Lev}+\varepsilon \ldots \ldots .(3)$ Model 3: $\mathrm{ROE}=\beta 0+\beta 1 \mathrm{HC}+\beta 2 \mathrm{SC}+\beta 3 \mathrm{ICE}+$ $\beta 4 \mathrm{RC}+\beta 5 \ln F$ Size $+\beta 6 \mathrm{Lev}+\varepsilon \ldots \ldots$ (4)

Model 4: $\mathrm{RONW}=\beta 0+\beta 1 \mathrm{HC}+\beta 2 \mathrm{SC}+\beta 3 \mathrm{CE}+\beta 4 \mathrm{RC}+$ $\beta 5 \ln F$ Size $+\beta 6$ Lev $+\varepsilon \ldots(5)$

\section{RESULTS AND DISCUSSION}

The results of Normality test, for intellectual capital performance and firm performance of the Indian Automobile Industry, are provided in Table-1. It is noted that HCE, SCE, CEE, RCE and MVAIC were used as independent variables, to assess the intellectual capital performance while ROA, ROE, RONW and ATO were used as dependent variables, to understand the nature of firm performance of Automobile Industry in India while Size and Leverage were considered as control variables, during the study period. The descriptive statistics, showing the results of Indian Automobile Industry, revealed that the value generated by intellectual capital performance variables, moved, during the study period, between minimum values of 1.340 (HCE) 0.738 (SCE) 0.489 (CEE) 0.001 (RCE) 2.568 (MVAIC) -1.70 (ROA) -28.38 (ROE) -60.310 (RONW) 0.011 (ATO) 6.552 (Size) and 0.330 (Leverage) to the maximum values of 2.354 (HCE) 0.905 (SCE) 1.141 (CEE) 0.007 (RCE) 4.232 (MVAIC) 0.70 (ROA) 24.25 (ROE) 25.700 (RONW) 0.047 (ATO) 1.800 (Size) and 2.360 (Leverage) during the study period. Simultaneously, the mean values of HCE, SCE, CEE, RCE, MVAIC, ROA, ROE, RONW, ATO, Size, Leverage were at $2.050,0.864,0.714,0.002,3.630,-0.212,3.435,8.124$, $0.032,1346,1.376$ and standard deviation values of $\mathrm{HCE}$, SCE, CEE, RCE, MVAIC, ROA, ROE, RONW, ATO, Size, Leverage were at $0.317,0.051,0.193,0.001,0.463,0.866$, $17.115,30.505,0.011,4.048,0.735$ accordingly. It is clear the highest mean value was recorded by HCE (2.050) followed by SCE (0.864) CEE (0.714) and RCE (0.002), for Indian Automobile Industry. It is to be noted from the mean values that Capital Employed Efficiency recorded a value of 0.714, lesser than HCE. In other words, CEE of Indian Automobile Industry was unable to create more value, from its physical assets, as HCE did.

The results of correlation analysis, for intellectual capital performance and firm performance of the Automobile Industry in India, during the study period, are displayed in Table-2. The analysis of Pearson Correlation Matrix reveals that values of correlation coefficient were at 0.991 for SCE with HCE, 0.915 for MVAIC with HCE, 0.927 for MVAIC with SCE, 0.649 for MVAIC with CEE, 0.905 for ROA with HCE, 0.884 for ROA-SCE, 0.884 for ROA-MVAIC, 0.789 for ROE with HCE, 0.794 for ROE with SCE, 0.839 for ROE with MVAIC, 0.832 for ROE with ROA, 0.886 for RONW with HCE, 0.865 for RONW-SCE, 0.868 for RONW-MVAIC, -0.635 for Size with HCE, -0.614 for Size with SCE, -0.654 for Size with CEE, -0.777 for Size with MVAIC, -0.826 for Size with ROA, --0.847 for Size with ROE, -0.854 for Size with RONW, 0.627 for Size with ATO, 0.820 for Leverage with HCE, 0.789 for Leverage with SCE, 0.694 for Leverage with MVAIC, 0.881 for Leverage with ROA, 0.804 for Leverage with ROE, 0.908 for Leverage with
RONW, - 0.765 for Leverage with Size. It is clear that twenty one sets (SCE-HCE, MVAIC-HCE, MVAIC-SCE, ROA-HCE, ROA-SCE, ROA-MVAIC, ROE-HCE, ROE-SCE, ROE-MVAIC, ROE-ROA, RONW-HCE, RONW-SCE, RONNW-MVAIC, RONW-ROA, RONW-ROE, Leverage-HCE, Leverage-SCE, Leverage-MVAIC, Leverage-ROA, Leverage-ROE, Leverage-RONW, Leverage-Size) had recorded significant relationship positively, at $99 \%$ confidence level (i.e., p value was less than 0.01). Some sets of sample variables, namely, MVAIC-CEE Size-ATO and Leverage- MVAIC registered positive relationship, at $95 \%$ confidence level (i.e., p value was less than 0.05). It is to be noted that a variable set, namely, Size with HCE, SCE, CEE and MVAIC, ROA, ROE and RONW witnessed negative association at 95 and $99 \%$ confidence level respectively. It is found that Leverage was also negatively associated with Size at $99 \%$ confidence level. Hence the null hypothesis (NH-2), namely, NH-1: No Relationship between Modified Value Added Intellectual Coefficient and the financial performance of Automobile Industry in India, was partially rejected.

Table-3 shows the outcome of regression analysis, for intellectual capital performance and firm performance of the Automobile Industry in India, during the study period. It is clear that coefficient values of HCE, SCE, CEE, RCE, MVAIC, Size and Leverage of ROA were at $0.905,-2.233$, $-1.2930 .291,3.763,-0.365$ and 0.603 with the t-statistic values of $6.369-2.461,-2.923,2914,3,356,-1.624$ and 2.682 in respect of Automobile Industry in India. Regarding ROE, coefficient values were at 3.847 (HCE) -1.129 (SCE) -0.509 (CEE) 0.418 (RCE) 2.173 (MVAIC) -0.559 (Size) 0.377 (Leverage) with the t-statistic values of 3.847, $-0.800-0.739$, $2.695,1.246,-2.155$ and 1.453 respectively. For RONW, the coefficient values were recorded by HCE at 0.886 , SCE at -2.277, CEE at -1.300, RCE at 0.291, MVAIC at 3.792, Size at -0.384 and Leverage at 0614 with the t-statistic values of $5.719,-1.999,-2.340,2.694,-2.066$ and 3.300. In case of ATO, coefficient values were recorded for HCE (-0.434) SCE (5.625) CEE (2.622) RCE (-0.011) MVAIC (-7.388) Size (0.643) Leverage (0.021), with the t-statistic values of $-1.447,2.256,2.157,-0.040,-2.398 \quad 1.503$ and 0.049 respectively. Further, the probability values of significantly influenced variables (ROA) were at 0.000 for HCE, 0.027 for RCE, 0.015 for MVAIC and 0.603 for Leverage. Considering ROE, the p-values were at 0.004 for HCE, 0.036 for RCE. RONW was positively caused by the variables namely, SCE (0.093) RCE (0.059 MVAIC (0.036) and Leverage (0.011). SCE and CEE positively impacted the value of the bank (ATO), at the p-value of 0.065 and 0.074 , with the confidence level of $95 \%$ and $99 \%$, during the study period. SCE negatively influenced ROA and RONW, followed by Size and the CEE also had reported negative impact on RONW. ATO was influenced negatively by MVAIC. It is clear that RCE, known as the proxy of relational capital, acted a role in creation of profitability (financial performance) of sample firms Automobile Industry, as shown in the Table. It is to be noted that Adjusted R-squared value was used to test the fitness of the regression model, with values of 0.909 for ROA, 0.780 for ROE, 0.857 for

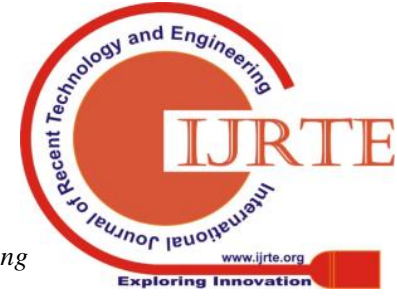


RONW and 0.313 for ATO. The test for measuring the impact of intellectual capital on firm performance of Indian Automobile Industry revealed that the regression model was perfectly fitted. Hence, the null hypothesis "NH-2 - No impact of Modified Value Added Intellectual Coefficient on the financial performance of Automobile Industry in India" was rejected.

\section{Findings}

The MVAIC recorded a value of 3.834, which implied that Indian Automobile Industry produced an average value of Indian rupee 3.834 , for each one Indian rupee spent by firms on intangible assets. The total value of RONW recorded the highest mean value among the sample variables like ROA, ROE and ATO, indicating that the Indian Automobile Industry mobilized high profits. ROE also recorded a high mean value, next to RONW, creating a higher profit. It is shocking to note, from the results of statistics that ROA of the sample firms had recorded the lowest mean values, revealing that the Indian Automobile Industry faced difficulties in earning profit over its ROA, unlike RCE, which reported the lowest standard deviation value, causing low variation in relational capital among other variables. On high standard deviation, it is inferred that RONW recorded high value. It is to be noted that there was high variation in the return on net worth, during the study period.

\section{E. Suggestions}

It is significant that these findings are important for different stakeholders because it would make them realize the significance of human capital, and necessary strategies, regarding training and development of employees, working in Automobile Industry in India. The managers of sample firms should use the findings, to increase the investments on intangible assets (intellectual capital), to build sustainable and competitive advantages. Moreover, rating agencies may learn from the results, to measure the efficiency of human capital also for the sample firms of automobile industry. The policy makers in India, should provide tax respite and incentives, to encourage automobile industry.

\section{F. Limitations}

For the purpose of this study, only two control variables, namely (Size and Leverage), were used due to lack of sufficient data available with the database.

\section{CONCLUSION}

The very purpose of the research was to examine, the effect of intellectual capital and its components on the financial performance of automobile industry in India, during the study period. The overall results clearly showed that the increase in values of all the sub components of MVAIC, except capital employed and relational capital, drove the increase in value of ROA, ROE and RONW. It is found that the relational capital did not contribute to firm performance in automobile industry in India, during the study period. A control variable (Size) decreased the values of financial performance (ROA, ROE, RONW, ATO) of sample firms. Modified Intellectual capital performance of automobile industry in India was associated with the values of the sample firms. The financial performance variables (ROA and
RONW) of sample firms, were greatly influenced by MVAIC, during the study period.

\section{A. Scope for further research}

The finding of this study may be useful to the business people, belonging to service industries (Information Technology, Pharmaceutical, and Financial Services, including Banking). Hence, future research could be conducted, using proxy variables with firm performance variables. Other measurement models like E-VAIC can be employed, to provide consistent results.

\section{REFERENCES}

1. Ahangar, (2011). The relationship between intellectual capital and financial performance: An empirical investigation in an Iranian company. African journal of business management, 5(1), 88-95.

2. Appuhami, (2007). The impact of intellectual capital on investors' capital gains on shares: an empirical investigation of Thai banking, finance and insurance sector. International Management Review, 3(2), 14-25.

3. Bharathi Kamath, (2008). Intellectual capital and corporate performance in Indian pharmaceutical industry. Journal of Intellectual Capital, 9(4), 684-704.

4. Bollen, Vergauwen, and Schnieders, (2005). Linking intellectual capital and intellectual property to company performance. Management Decision, 43(9), 1161-1185.

5. Bramhandkar, Erickson, and Applebee, (2007). Intellectual capital and organizational performance: An empirical study of the pharmaceutical industry. In ECKM2007-Proceedings of the 8th European Conference on Knowledge Management: ECKM (p. 147). Academic Conferences Limited.

6. Canibano, Garcia-Ayuso and Sanchez, (1999a), "The value relevance and managerial implications of intangibles: a literature review", paper presented at the International Symposium Measuring and Reporting Intellectual Capital: Experiences, Issues and Prospects, June, Amsterdam.

7. Chen, (2005). Intellectual capital performance of commercial banks in Malaysia. Journal of intellectual capital, 6(3), 385-396.

8. Chen Cheng, and Hwang, (2005). An empirical investigation of the relationship between intellectual capital and firms' market value and financial performance. Journal of intellectual capital, 6(2), 159-176.

9. Choudhury, (2010). Performance impact of intellectual capital: a study of Indian IT sector. International journal of business and management, 5(9), 72

10. Clarke, Seng and Whiting, (2011). Intellectual capital and firm performance in Australia. Journal of Intellectual Capital, 12(4), 505-530.

11. Dženopoljac, Janoševic, and Bontis, (2016). Intellectual capital and financial performance in the Serbian ICT industry. Journal of Intellectual Capital, 17(2), 373-396.

12. Edvinsson and Malone, (1997), Intellectual Capital: The Proven Way to Establish Your Company's Real Value by Measuring Its Hidden Brain Power, Piatkus, London.

13. Kaplan and David, (1996). Norton. 1996. The balanced scorecard: translating strategy into action.

14. Keong Choong, (2008). Intellectual capital: definitions, categorization and reporting models. Journal of intellectual capital, 9(4), 609-638.

15. Makki and Lodhi (2009). Impact of intellectual capital on return on investment in Pakistani corporate sector. Australian Journal of Basic and Applied Sciences, 3(3), 2995-3007.

16. Maria Morariu, (2014). Intellectual capital performance in the case of Romanian public companies. Journal of Intellectual Capital, 15(3), $392-410$.

17. Mondal and Ghosh, (2015). A Study on Effectiveness of Investment in Intellectual Capital of Indian Knowledge Companies. International Journal of Business Analytics and Intelligence, 3(2), 65.

18. Mouritsen, Larsen and Bukh (2001). Intellectual capital and the 'capable firm': narrating, visualising and numbering for managing knowledge. Accounting, organizations and society, 26(7-8), 735-762.

19. Murugesan Vadivel Chinnadurai and Dhamotharan, (2018). Intellectual Capital: Its Effect on Financial Performance of Indian Private Sector Banks. 
20. Nadeem, Gan, and Nguyen, (2017). Does intellectual capital efficiency improve firm performance in BRICS economies? A dynamic panel estimation. Measuring Business Excellence, 21(1), 65-85.

21. Nazari, and Herremans, (2007). Extended VAIC model: measuring intellectual capital components. Journal of Intellectual Capital, 8(4), 595-609.

22. Pew Tan, Plowman, and Hancock, (2007). Intellectual capital and financial returns of companies. Journal of Intellectual capital, 8(1), 76-95.

23. Roos, Edvinsson, and Dragonetti, (1997). Intellectual capital: Navigating the new business landscape. Springer.

24. Smriti and Das, (2018). The impact of intellectual capital on firm performance: a study of Indian firms listed in COSPI. Journal of Intellectual Capital, 19(5), 935-964.

Table-1: Results of Descriptive Statistics for Intellectual Capital Performance and Firms' Financial Performance of Automobile Industry in India

\begin{tabular}{|c|c|c|c|c|c|}
\hline Independent Variables & $\mathbf{N}$ & Minimum & Maximum & Mean & S.D \\
\hline HCE & 15 & 1.340 & 2.354 & 2.050 & 0.317 \\
\hline SCE & 15 & 0.738 & 0.905 & 0.864 & 0.051 \\
\hline CEE & 15 & 0.489 & 1.141 & 0.714 & 0.193 \\
\hline RCE & 15 & 0.001 & 0.007 & 0.002 & 0.001 \\
\hline MVAIC & 15 & 2.568 & 4.232 & 3.630 & 0.463 \\
\hline Dependent Variables & \multirow{2}{*}{15} & \multirow[b]{2}{*}{-1.70} & \multirow[b]{2}{*}{0.70} & \multirow[b]{2}{*}{-0.212} & \multirow[b]{2}{*}{0.866} \\
\hline ROA & & & & & \\
\hline ROE & 15 & -28.38 & 24.25 & 3.435 & 17.115 \\
\hline RONW & 15 & -60.310 & 25.700 & 8.124 & 30.505 \\
\hline ATO & 15 & 0.011 & 0.047 & 0.032 & 0.011 \\
\hline Control Variables & \multirow{2}{*}{15} & \multirow[b]{2}{*}{6.552} & \multirow[b]{2}{*}{1.800} & \multirow[b]{2}{*}{1.346} & \multirow[b]{2}{*}{4.048} \\
\hline Size & & & & & \\
\hline Leverage & 15 & 0.330 & 2.360 & 1.376 & 0.735 \\
\hline
\end{tabular}

Source: Data extracted from CMIE ProwessIQ database and computed using IBM SPSS 16.0
25. Steward, Intellectual Capital, Bantam Doubleday Dell Publishing Group, New York 1997

26. Sveiby, (1997), The intangible asset monitor, Journal of Human Resource Costing and Accounting, Vol. 2 No. 1, pp. 73-97.

27. Tether and Tajar, (2008). The organisational-cooperation mode of innovation and its prominence amongst European service firms. Research policy, 37(4), 720-739.

28. Vishnu and Kumar Gupta, (2014). Intellectual capital and performance of pharmaceutical firms in India. Journal of Intellectual Capital, 15(1), 83-99. 
The Influence Of Intellectual Capital On Firms Performance Of Indian Automobile Industry

Table-2: Results of Relationship between Intellectual Capital Performance and Firms' Financial Performance of Automobile Industry in India

\begin{tabular}{|c|c|c|c|c|c|c|c|c|c|c|c|c|}
\hline & Variables & HCE & SCE & CEE & RCE & MVAIC & ROA & ROE & RONW & ATO & Size & Leverage \\
\hline HCE & $\begin{array}{l}\text { Pearson Correlation } \\
\text { Sig. (2-tailed) }\end{array}$ & 1 & & & & & & & & & & \\
\hline SCE & $\begin{array}{l}\text { Pearson Correlation } \\
\text { Sig. (2-tailed) }\end{array}$ & $\begin{array}{c}0.991 * * * \\
0.000\end{array}$ & 1 & & & & & & & & & \\
\hline CEE & $\begin{array}{l}\text { Pearson Correlation } \\
\text { Sig. (2-tailed) }\end{array}$ & $\begin{array}{l}0.286 \\
0.393\end{array}$ & $\begin{array}{l}0.328 \\
0.324\end{array}$ & 1 & & & & & & & & \\
\hline RCE & $\begin{array}{l}\text { Pearson Correlation } \\
\text { Sig. (2-tailed) }\end{array}$ & $\begin{array}{l}0.158 \\
0.643\end{array}$ & $\begin{array}{l}0.182 \\
0.592\end{array}$ & $\begin{array}{l}-0.070 \\
0.838\end{array}$ & 1 & & & & & & & \\
\hline MVAIC & $\begin{array}{c}\text { Pearson Correlation } \\
\text { Sig. (2-tailed) }\end{array}$ & $\begin{array}{c}0.915 * * * \\
0.000\end{array}$ & $\begin{array}{c}0.927 * * * \\
0.000\end{array}$ & $\begin{array}{c}0.649 * * \\
0.031\end{array}$ & $\begin{array}{l}0.103 \\
0.764 \\
\end{array}$ & 1 & & & & & & \\
\hline ROA & $\begin{array}{l}\text { Pearson Correlation } \\
\text { Sig. (2-tailed) }\end{array}$ & $\begin{array}{c}0.905 * * * \\
0.000\end{array}$ & $\begin{array}{c}0.884 * * * \\
0.000\end{array}$ & $\begin{array}{l}0.396 \\
0.228\end{array}$ & $\begin{array}{l}0.361 \\
0.275\end{array}$ & $\begin{array}{c}0.884 * * * \\
0.000\end{array}$ & 1 & & & & & \\
\hline ROE & $\begin{array}{l}\text { Pearson Correlation } \\
\text { Sig. (2-tailed) }\end{array}$ & $\begin{array}{c}0.789 * * * \\
0.004\end{array}$ & $\begin{array}{c}0.794 * * * \\
0.004\end{array}$ & $\begin{array}{l}0.501 \\
0.116\end{array}$ & $\begin{array}{l}0.472 \\
0.143\end{array}$ & $\begin{array}{c}0.839 * * * \\
0.001\end{array}$ & $\begin{array}{c}0.832 * * * \\
0.001\end{array}$ & 1 & & & & \\
\hline RONW & $\begin{array}{c}\text { Pearson Correlation } \\
\text { Sig. (2-tailed) }\end{array}$ & $\begin{array}{c}0.886 * * * \\
0.000\end{array}$ & $\begin{array}{c}0.865 * * * \\
0.001 \\
\end{array}$ & $\begin{array}{l}0.393 \\
0.231 \\
\end{array}$ & $\begin{array}{l}0.357 \\
0.281 \\
\end{array}$ & $\begin{array}{c}0.868 * * * \\
0.001 \\
\end{array}$ & $\begin{array}{c}0.992 * * * \\
0.000 \\
\end{array}$ & $\begin{array}{c}0.835^{* * * *} \\
0.001 \\
\end{array}$ & 1 & & & \\
\hline ATO & $\begin{array}{l}\text { Pearson Correlation } \\
\text { Sig. (2-tailed) }\end{array}$ & $\begin{array}{l}-0.434 \\
0.182 \\
\end{array}$ & $\begin{array}{l}-0.365 \\
0.269 \\
\end{array}$ & $\begin{array}{c}-0.326 \\
0.328 \\
\end{array}$ & $\begin{array}{l}0.070 \\
0.837\end{array}$ & $\begin{array}{c}-0.474 \\
0.141 \\
\end{array}$ & $\begin{array}{l}-0.418 \\
0.201 \\
\end{array}$ & $\begin{array}{c}-0.552^{*} \\
0.078\end{array}$ & $\begin{array}{l}-0.441 \\
0.174 \\
\end{array}$ & 1 & & \\
\hline Size & $\begin{array}{l}\text { Pearson Correlation } \\
\text { Sig. (2-tailed) }\end{array}$ & $\begin{array}{c}-0.635^{* *} \\
0.036\end{array}$ & $\begin{array}{c}-0.614 * * \\
0.044\end{array}$ & $\begin{array}{c}-0.654 * * \\
0.029\end{array}$ & $\begin{array}{l}-0.322 \\
0.334\end{array}$ & $\begin{array}{c}-0.777 * * * \\
0.005\end{array}$ & $\begin{array}{c}-0.826^{* * * *} \\
0.002\end{array}$ & $\begin{array}{c}-0.847 * * * \\
0.001\end{array}$ & $\begin{array}{c}-0.854^{* * *} \\
0.001\end{array}$ & $\begin{array}{c}0.627^{* *} \\
0.039\end{array}$ & 1 & \\
\hline Leverage & $\begin{array}{c}\text { Pearson Correlation } \\
\text { Sig. (2-tailed) } \\
\text { N }\end{array}$ & $\begin{array}{c}0.820 * * * \\
0.002 \\
15\end{array}$ & $\begin{array}{c}0.789 * * * \\
0.004 \\
15\end{array}$ & $\begin{array}{c}0.103 \\
0.764 \\
15\end{array}$ & $\begin{array}{c}0.438 \\
0.178 \\
15\end{array}$ & $\begin{array}{c}0.694^{* *} \\
0.018 \\
15\end{array}$ & $\begin{array}{c}0.881 * * * \\
0.000 \\
15\end{array}$ & $\begin{array}{c}0.804 * * * \\
0.003 \\
15\end{array}$ & $\begin{array}{c}0.908 * * * \\
0.000 \\
15\end{array}$ & $\begin{array}{c}-0.470 \\
0.144 \\
15\end{array}$ & $\begin{array}{c}-0.765^{* * *} \\
0.006 \\
15\end{array}$ & $\begin{array}{c}1 \\
15\end{array}$ \\
\hline
\end{tabular}

Source: Data extracted from CMIE ProwessIQ database and computed using IBM SPSS 16.0

Note: * indicates statistically significant. 
Table-3: Results for the Impact of Intellectual Capital on Firm Performance of Automobile Industry in India.

\begin{tabular}{|c|c|c|c|c|}
\hline Variables & ROA & ROE & RONW & ATO \\
\hline Constant & $\begin{array}{c}0.181 \\
- \\
(1.511)\end{array}$ & $\begin{array}{c}0.788 \\
- \\
(0.282) \\
\end{array}$ & $\begin{array}{c}0.256 \\
- \\
(1.255) \\
\end{array}$ & $\begin{array}{c}0.099 \\
- \\
(-1.954)\end{array}$ \\
\hline HCE & $\begin{array}{c}0.000 * * * \\
0.905 \\
(6.369) \\
\end{array}$ & $\begin{array}{c}0.004 * * * \\
0.789 \\
(3.847) \\
\end{array}$ & $\begin{array}{c}0.000 * * * \\
0.886 \\
(5.719) \\
\end{array}$ & $\begin{array}{c}0.182 \\
-0.434 \\
(-1.447)\end{array}$ \\
\hline SCE & $\begin{array}{c}0.049 * * \\
-2.233 \\
(-2.461) \\
\end{array}$ & $\begin{array}{c}0.454 \\
-1.129 \\
(-0.800) \\
\end{array}$ & $\begin{array}{c}0.093^{*} \\
-2.277 \\
(-1.999) \\
\end{array}$ & $\begin{array}{c}0.065 * \\
5.625 \\
(2.256) \\
\end{array}$ \\
\hline CEE & $\begin{array}{c}0.027 * * \\
-1.293 \\
(-2.923) \\
\end{array}$ & $\begin{array}{c}0.488 \\
-0.509 \\
(-0.739) \\
\end{array}$ & $\begin{array}{c}0.058 * * \\
-1.300 \\
(-2.340) \\
\end{array}$ & $\begin{array}{c}0.074 * \\
2.622 \\
(2.157) \\
\end{array}$ \\
\hline RCE & $\begin{array}{c}0.027 * * \\
0.291 \\
(2.914) \\
\end{array}$ & $\begin{array}{c}0.036 * * \\
0.418 \\
(2.695) \\
\end{array}$ & $\begin{array}{c}0.059 * * \\
0.291 \\
(2.323) \\
\end{array}$ & $\begin{array}{c}0.970 \\
-0.011 \\
(-0.040)\end{array}$ \\
\hline MVAIC & $\begin{array}{c}0.015 * * * \\
3.763 \\
(3.356) \\
\end{array}$ & $\begin{array}{c}0.259 \\
2.173 \\
(1.246) \\
\end{array}$ & $\begin{array}{c}0.036 * * \\
3.792 \\
(2.694) \\
\end{array}$ & $\begin{array}{c}0.053 * * \\
-7.388 \\
(-2.398) \\
\end{array}$ \\
\hline Size & $\begin{array}{c}0.143 \\
-0.365 \\
(-1.624) \\
\end{array}$ & $\begin{array}{c}0.063 * \\
-0.559 \\
(-2.155) \\
\end{array}$ & $\begin{array}{c}0.073^{*} \\
-0.384 \\
(-2.066) \\
\end{array}$ & $\begin{array}{c}0.171 \\
0.643 \\
(1.503) \\
\end{array}$ \\
\hline Lev & $\begin{array}{c}0.028 * * \\
0.603 \\
(2.686) \\
\end{array}$ & $\begin{array}{c}0.184 \\
0.377 \\
(1.453)\end{array}$ & $\begin{array}{c}0.011 * * * \\
0.614 \\
(3.300)\end{array}$ & $\begin{array}{c}0.962 \\
0.021 \\
(0.049)\end{array}$ \\
\hline Adjust $\mathbf{R}^{2}$ & 0.909 & 0.780 & 0.857 & 0.313 \\
\hline $\mathbf{N}$ & 15 & 15 & 15 & 15 \\
\hline
\end{tabular}

Source: Data extracted from CMIE ProwessIQ database and computed using IBM SPSS 16.0

Note: * indicates statistically significant. 